\title{
Absence of cannabinoid 1 receptor in beta cells protects against high-fat/high-sugar diet-induced beta cell dysfunction and inflammation in murine islets
}

\author{
Isabel González-Mariscal ${ }^{1}$ • Rodrigo A. Montoro ${ }^{1}$ - Máire E. Doyle ${ }^{1}$ • Qing-Rong Liu ${ }^{1}$ • Michael Rouse ${ }^{1}$. \\ Jennifer F. O'Connell ${ }^{1}$. Sara Santa-Cruz Calvo ${ }^{1}$. Susan M. Krzysik-Walker ${ }^{1}$. Soumita Ghosh ${ }^{1}$ - Olga D. Carlson ${ }^{1}$. \\ Elin Lehrmann ${ }^{2} \cdot$ Yongqing Zhang ${ }^{2} \cdot$ Kevin G. Becker $^{2} \cdot$ Chee W. Chia $^{3} \cdot$ Paritosh Ghosh $^{1} \cdot$ Josephine M. Egan ${ }^{1}$
}

Received: 19 September 2017 / Accepted: 25 January 2018 / Published online: 1 March 2018

(C) The Author(s) 2018. This article is an open access publication

\begin{abstract}
Aims/hypothesis The cannabinoid 1 receptor $(\mathrm{CB} 1 \mathrm{R})$ regulates insulin sensitivity and glucose metabolism in peripheral tissues. $\mathrm{CB} 1 \mathrm{R}$ is expressed on pancreatic beta cells and is coupled to the $\mathrm{G}$ protein $\mathrm{G} \alpha \mathrm{i}$, suggesting a negative regulation of endogenous signalling in the beta cell. Deciphering the exact function of CB1R in beta cells has been confounded by the expression of this receptor on multiple tissues involved in regulating metabolism. Thus, in models of global genetic or pharmacological CB1R blockade, it is difficult to distinguish the indirect effects of improved insulin sensitivity in peripheral tissues from the direct effects of inhibiting CB1R in beta cells per se. To assess the direct contribution of beta cell CB1R to metabolism, we designed a mouse model that allows us to determine the role of CB1R specifically in beta cells in the context of whole-body metabolism.

Methods We generated a beta cell specific $\operatorname{Cnrl}(\mathrm{CB} 1 \mathrm{R})$ knockout mouse $\left(\beta-\mathrm{CB} 1 \mathrm{R}^{--}\right)$to study the long-term consequences of CB1R ablation on beta cell function in adult mice. We measured beta cell function, proliferation and viability in these mice in response to a high-fat/high-sugar diet and induction of acute insulin resistance with the insulin receptor antagonist S961.

Results $\beta-\mathrm{CB} 1 \mathrm{R}^{--}$mice had increased fasting $(153 \pm 23 \%$ increase at 10 weeks of age $)$ and stimulated insulin secretion and increased intra-islet cAMP levels ( $217 \pm 33 \%$ increase at 10 weeks of age), resulting in primary hyperinsulinaemia, as well as increased beta cell viability, proliferation and islet area (1.9-fold increase at 10 weeks of age). Hyperinsulinaemia led to insulin resistance, which was aggravated by a high-fat/high-sugar diet and weight gain, although beta cells maintained their insulin secretory capacity in response to glucose. Strikingly, islets from $\beta-\mathrm{CB} 1 \mathrm{R}^{-/-}$mice were protected from diet-induced inflammation. Mechanistically, we show that this is a consequence of curtailment of oxidative stress and reduced activation of the NLRP3 inflammasome in beta cells.

Conclusions/interpretation Our data demonstrate CB1R to be a negative regulator of beta cell function and a mediator of islet inflammation under conditions of metabolic stress. Our findings point to beta cell CB1R as a therapeutic target, and broaden its potential to include anti-inflammatory effects in both major forms of diabetes.
\end{abstract}

Data availability Microarray data have been deposited at GEO (GSE102027).

Electronic supplementary material The online version of this article (https://doi.org/10.1007/s00125-018-4576-4) contains peer-reviewed but unedited supplementary material, which is available to authorised users.

Josephine M. Egan

eganj@grc.nia.nih.gov

1 Laboratory of Clinical Investigation, National Institute on Aging, National Institutes of Health, 251 Bayview Boulevard,

Baltimore, MD 21224, USA

2 Laboratory of Genetics, National Institute on Aging, National Institutes of Health, Baltimore, MD, USA

3 Intramural Research Program, National Institute on Aging, National Institutes of Health, Baltimore, MD, USA
Keywords Beta cell - Beta cell proliferation - Beta cell viability · Cannabinoid 1 receptor · Diabetes · Inflammation · Insulin · Insulin resistance $\cdot$ Islet of Langerhans $\cdot$ Mouse

$\begin{array}{ll}\text { Abbreviations } \\ \text { AC } & \text { Adenylyl cyclase } \\ \text { CB1KO } & \text { Cannabinoid 1 receptor knockout } \\ \text { CB1R } & \text { Cannabinoid 1 receptor } \\ \beta-C B 1 R^{-/-} & \text {Beta cell specific cannabinoid } 1 \\ & \text { receptor knockout } \\ \text { CB2R } & \text { Cannabinoid } 2 \text { receptor } \\ \text { CLAMS } & \text { Comprehensive Lab Monitoring System }\end{array}$




\section{Research in context}

\section{What is already known about this subject?}

- Peripheral blockade of cannabinoid 1 receptor (CB1R) improves whole-body glucose metabolism

- $\quad \mathrm{CB} 1 \mathrm{R}$ is expressed in beta cells as well as in many other peripheral tissues

- The presence of CB1R in metabolically active tissues and its role in insulin sensitivity and glucose metabolism confound its specific role in pancreatic beta cells

\section{What is the key question?}

- What is the specific role of CB1R in pancreatic beta cells?

\section{What are the new findings?}

- Ablation of CB1R in beta cells allows increased beta cell proliferation and also augments early-phase insulin secretion

- In addition, diet-induced intra-islet inflammation is prevented by ablation of CB1R in beta cells

How might this impact on clinical practice in the foreseeable future?

- $\quad$ CB1R emerges as a target for treatment of (pre)diabetes that enhances beta cell function and viability

$\begin{array}{ll}\text { EC } & \text { Endocannabinoid } \\ \text { ECAR } & \text { Extracellular acidification rate } \\ \text { ECS } & \text { Endocannabinoid system } \\ \text { Ex-4 } & \text { Exendin-4 } \\ \text { FBG } & \text { Fasting blood glucose } \\ \text { GIP } & \text { Gastric inhibitory polypeptide } \\ \text { GLP-1 } & \text { Glucagon-like peptide } \\ \text { HFHS } & \text { High-fat/high-sugar diet } \\ \text { HGP } & \text { High glucose and palmitate } \\ \text { IBMX } & \text { 3-Isobutyl-1-methylxanthine } \\ \text { IR } & \text { Insulin receptor } \\ \text { MAPK } & \text { Mitogen-activated protein kinase } \\ \text { NLRP3 } & \text { NLR family, pyrin domain containing 3 } \\ \text { OCR } & \text { Oxygen consumption rate } \\ \text { RER } & \text { Respiratory exchange rate } \\ \text { ROS } & \text { Reactive oxygen species } \\ \text { SD } & \text { Standard diet (assignment group) } \\ \text { TXNIP } & \text { Thioredoxin-interacting protein }\end{array}$

\section{Introduction}

Insulin secretion is tightly controlled as dysregulation has lifethreatening consequences. When chronically stimulated, beta cell function deteriorates, and insufficient insulin secretion, especially when coupled with insulin resistance, causes glucose elevation and type 2 diabetes. Glucose metabolism is the primary trigger for insulin secretion, while other factors such as gastric inhibitory polypeptide (GIP) and glucagon-like peptide (GLP1), cholecystokinin, amino acids (leucine and arginine) and acetylcholine enhance glucose-mediated insulin secretion $[1,2]$.
Negative regulators exist, with adrenaline (epinephrine), noradrenaline (norepinephrine) and somatostatin being the most studied $[1,3]$. The endocannabinoid system (ECS) also has a regulatory role in beta cells. In humans and rodents, beta cells express the cannabinoid 1 receptor (CB1R, encoded by $C n r 1)$, synthesise endocannabinoids (ECs) in a glucose-dependent manner $[4,5]$ and contain the enzymes necessary for EC degradation $[4,6-8]$. In obesity, the ECS becomes overactive $[8,9]$.

CB1R is coupled to the $G$ protein type $G_{i / o}$, G $\alpha$, which inhibits adenylyl cyclase (AC) and cAMP-protein kinase A signalling, activates mitogen-activated protein kinases (MAPKs) and stimulates ceramide synthesis in many tissues [10-13]. It also inhibits voltage-gated L-, N- and P/Q-type $\mathrm{Ca}^{2+}$ channels, inwardly rectifying $\mathrm{K}^{+}$channels and leading to inhibition of signal transmission and release of secretory products $[14,15]$. These complex but connected signalling pathways impact on many physiological processes, including exocytosis, cell survival and differentiation, metabolism and immune cell responses $[11,16]$. Coupling CB1R to the $\mathrm{G}_{\alpha \mathrm{i}}$ protein indicates a potential negative regulatory role in beta cells, where $\mathrm{AC}$ positively regulates insulin secretion and beta cell function. We and others have dissected the actions of CB1R in metabolically active tissues using wholebody Cnrl (CB1R) knockout (CB1KO) rodents [17, 18] and pharmacological approaches [8, 19-24]. Nonetheless, the complexity of CB1R's action, its presence in numerous tissues and the potential off-target effects of pharmacological approaches have confounded the study of CB1R in beta cells. The effects of specifically targeting CB1R in pancreatic beta cells and whether this has direct effects on beta cell function and/or whole-body metabolism have not been studied.

To further interrogate the functions of CB1R in adult beta cells, and to build upon previous work on CB1R blockers as 
therapeutic agents for obesity-related disorders, we generated an inducible beta cell specific CB1R knockout $\left(\beta-\mathrm{CB} 1 \mathrm{R}^{-/}\right)$ mouse and studied the implications of CB1R ablation in beta cells under conditions of acute and chronic insulin resistance in vivo and ex vivo.

\section{Methods}

For detailed methods, please refer to the electronic supplementary material (ESM) Methods.

Materials All materials and mouse strains used in this study are detailed in ESM Tables 1-7.

Animals Animal care and procedures were approved by the National Institute on Aging Animal Care and Use Committee. Mice were housed in groups of four using $12 \mathrm{~h}$ dark/light cycles, provided with water and fed ad libitum. $C n r I^{\text {flox/flox }}$ mice were generated as described in the ESM Methods. $\mathrm{Cnr} \mathrm{I}^{\text {flox/flox }}$ mice were mated with MIP-Cre/ERT mice (University of Chicago, Chicago, IL, USA) and injected daily for 5 days with i.p. tamoxifen to obtain $\beta-\mathrm{CB} 1 \mathrm{R}^{-/-}$mice $\left(\mathrm{Cnr} \mathrm{l}^{\text {flox/flox }}\right.$ :MIP$\left.\mathrm{Cre} / \mathrm{ERT}^{+}\right), \beta-\mathrm{CB} 1 \mathrm{R}^{+/+}$control littermates $\left(\mathrm{Cnr} 1^{\text {flox/flox }}\right.$ :MIP$\left.\mathrm{Cre} / \mathrm{ERT}^{-}\right)$and MIP-Cre/ERT mice $\left(C n r 1^{\mathrm{wt} / \mathrm{wt}}: \mathrm{MIP}-\mathrm{Cre} /\right.$ ERT $^{+}$). CB1KO mice (NIH, Bethesda, MD, USA) were bred as described in the ESM Methods. Male mice $(n=6-7$ mice/group) were aged to 25 weeks and body weights and metabolic variables were analysed. Body composition was analysed using NMR. Pancreases were fixed and processed for immunohistochemistry (anti-insulin [1:100; Dako], antiglucagon [1:500; Sigma-Aldrich], anti-BrdU [1:100; Accurate Chemicals]). Islet size was quantified using Pancreas++ [25]. Hormones were quantified using ELISA. Methanol-chloroform-extracted ECs from plasma were analysed using LCMS/MS, as described in the ESM Methods.

Induction of acute insulin resistance Male mice $(n=8-11$ mice/group) were randomised to receive vehicle or S961 $(0.05 \mathrm{nmol} / \mathrm{h})$ via ALZET miniosmotic pumps. Blood glucose and insulin levels were measured from tail bleed at 0-6 days; mice were injected with $\mathrm{BrdU}(0.1 \mathrm{nmol} / \mathrm{g})$ and euthanised $12 \mathrm{~h}$ later.

Diet-induced obesity Male mice (6-8 weeks old; $n=6-7$ / group) were randomised to a standard diet $(16.7 \% \mathrm{~kJ}$ fat and $12.4 \% \mathrm{~kJ}$ sugar wt/wt) or high-fat/high-sugar diet (HFHS; $49.2 \% \mathrm{~kJ}$ fat and $32.2 \% \mathrm{~kJ}$ sugar wt/wt) for 15 weeks. Body weight and food consumption were measured weekly. At the end of the study, GTTs and metabolic measurements were performed. Metabolic measurements were measured using a Columbus Instruments Comprehensive Lab Monitoring System (CLAMS; Columbus Instruments), as described in ESM. Tissues (pancreas, liver and white adipose tissue) were dissected, weighed and flash frozen or fixed for immunohistochemistry (anti-CD3, anti-CD68, anti-thioredoxin-interacting protein [TXNIP] and anti-phospho [p][S536]-p65 [1:100; Abcam], anti-ceramide [1:10; Enzo Life Sciences]). Immunoprecipitated insulin receptor (IR) or IRS-2 from liver protein extracts (anti-IRS2 [Cell Signaling], anti-IR [Santa Cruz Biotechnology]; $1 \mu \mathrm{g}$ ) were subjected to Trisglycine PAGE, immunoblotted with anti-IRS2 or anti-p-Tyr (1:1000; Santa Cruz Biotechnology), visualised by enhanced chemiluminescence and quantified using ImageJ.

Ex vivo analysis of viability and metabolism of isolated islets Freshly isolated islets were cultured in non-stimulatory conditions $(2 \mathrm{mmol} / \mathrm{lglucose})$ to quantify basal cAMP $(n=100$ islets/mouse) and resting insulin secretion ( $n=40$ islets/mouse). Islets were cultured with exendin-4 (Ex-4) and 3-isobutyl-1methylxanthine (IBMX; $25 \mu \mathrm{mol} / \mathrm{l}$; Sigma-Aldrich), and intra-islet cAMP levels and insulin secretion were quantified. Islets ( $n=100-120$ islets/mouse) were infused with glucose ( $7.5 \mathrm{mmol} / \mathrm{l})$ in a perifusion system and insulin secretion was quantified. Freshly isolated islets ( $n=30$ islets/group) were used to measure the oxygen consumption rate (OCR), extracellular acidification rate (ECAR) using an XFe24 Seahorse Analyzer (Agilent) and intra-islet levels of reactive oxygen species (ROS) as described in ESM. Islets ( $n=30-50$ islets/group) were cultured in the presence or absence of $500 \mu \mathrm{mol} / \mathrm{l} \mathrm{palmi-}$ tate and $16.5 \mathrm{mmol} / \mathrm{l}$ glucose for $24 \mathrm{~h}$. Islet viability, cAMP levels, mRNA expression (Illb, Nlrp3, Tnfa [also known as Tnf], Ldha), cytokine secretion (IL-1 $\beta$, TNF- $\alpha$ ), protein phosphorylation (p-Erk1/2, p-SAPK/JNK, p-p38, p-p53, p-Stat1, pHSP27) and cleavage (caspase 3, PARP) were measured. Islets ( $n=15$ islets/group) were incubated with a mixture of cytokines (10 ng/ml IL- $1 \beta, 50 \mathrm{ng} / \mathrm{ml}$ TNF- $\alpha$ and $50 \mathrm{ng} / \mathrm{ml} \mathrm{IFN-} \gamma$ ) or vehicle for $18 \mathrm{~h}$ and cytotoxicity was assayed. There were at least three replicates in all experiments.

Flow cytometry Pancreatic lymphocytes were isolated after pancreas perfusion and cells were stained using PE anti-mouse CD8a and FITC anti-mouse CD69 (Biolegend), as detailed in the ESM Methods. Populations were determined by using BD FACSCanto II and BD FACSDiva software (BD Biosciences).

Microarray analysis Microarray experiments and analysis were performed as previously described [26].

Method of randomisation Age and sex-matched littermate mice were randomly assigned to vehicle, S961, standard diet or HFHS.

Quantification and statistical analysis Data are presented as means \pm SEM. No statistical method was used to predetermine the sample size. Differences between mean values for variables within individual experiments were compared 
Fig. 1 Insulin levels, glucose levels and beta cell proliferation in $\beta-\mathrm{CB} 1 \mathrm{R}^{-/-}$mice. (a) Schematic of the experimental design. Six-week-old MIP-Cre/ ERT-Cnr $1^{\text {flox/flox }}$ mice were injected with i.p. tamoxifen for 5 consecutive days. (b) Body weight, (c) fasting plasma insulin and (d) FBG levels in $\beta-\mathrm{CB} 1 \mathrm{R}^{+/+}$ and $\beta-\mathrm{CB} 1 \mathrm{R}^{-/-}$mice were measured at the indicated ages. (e) IPGTTs and (f) mixed glucoselipid stimulated insulin secretion were examined at 25 weeks of age. (g) Mice were injected with BrdU prior to euthanasia at 8,9 and 10 weeks of age. (h) Immunostaining for insulin (red), BrdU (white; green arrow) and nuclei (DAPI; blue) in pancreases from $\beta-\mathrm{CB} 1 \mathrm{R}^{+/+}$and $\beta-\mathrm{CB} 1 \mathrm{R}^{-/-}$ mice (scale bars, $50 \mu \mathrm{m}$ ). (i) Analysis of beta cell proliferation (\% BrdU-positive beta cells/total beta cells) and (j) islet area $(n=$ 100 islets/group). (k) Relative mRNA expression of $I g f 1$ and $\operatorname{Ig} f 2$ in isolated islets. $n=6$ mice in 6- and 25 -week old $\beta-\mathrm{CB} 1 \mathrm{R}^{+/+}$ groups and in 6- and 8-week old $\beta-\mathrm{CB} 1 \mathrm{R}^{-/-}$groups; $n=7$ mice in 7-10-week old $\beta$-CB1 ${ }^{+/+}$ groups and in 7-, 9-, 10- and 25week old $\beta-\mathrm{CB} 1 \mathrm{R}^{-/}$groups. Black circles/bars, $\beta-\mathrm{CB} 1 \mathrm{R}^{+/+}$; white circles/bars, $\beta-\mathrm{CB} 1 \mathrm{R}^{-/-}$. Data are means \pm SEM. Significance by ANOVA or $t$ test, $* p \leq 0.05, * * p \leq 0.01, * * * p \leq$ $0.001 \mathrm{vs} \beta-\mathrm{CB}_{1} \mathrm{R}^{+/+} ;{ }^{\dagger} p \leq 0.05 \mathrm{vs}$ week 0. See also ESM Figs. 1,2

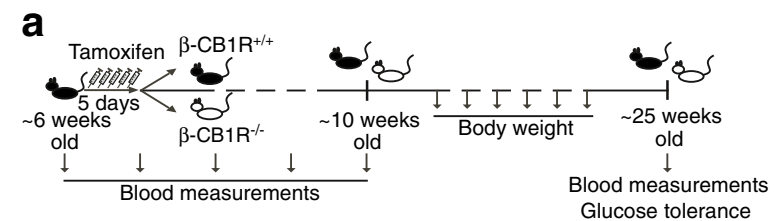

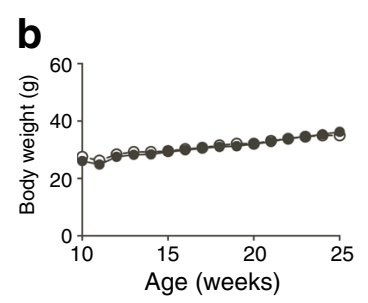
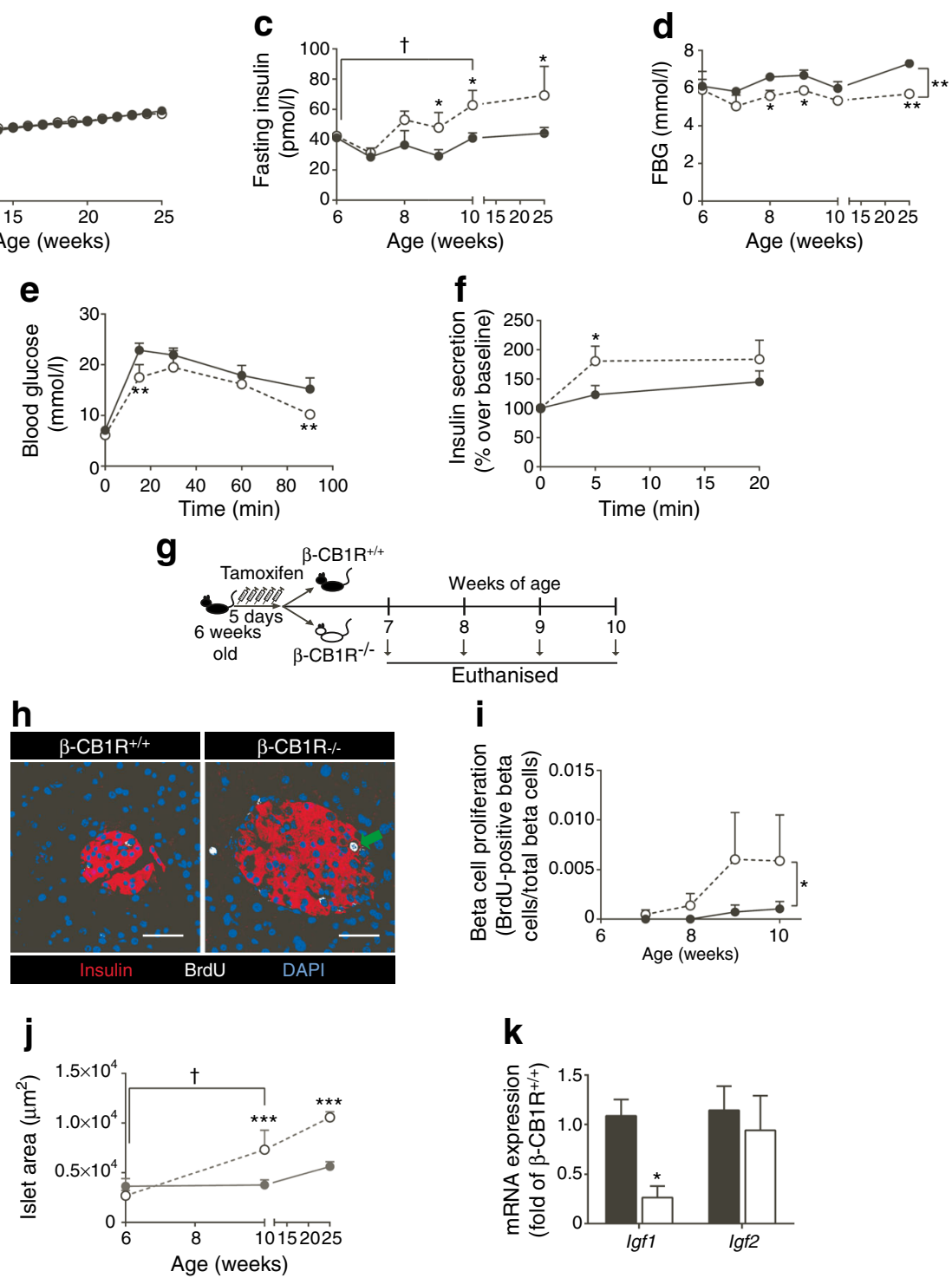

statistically using Student's $t$ test or ANOVA, as appropriate. Comparisons were performed using GraphPad Prism version 6.0. $p \leq 0.05$ was considered statistically significant.

\section{Results}

$\beta-C B 1 R^{-/-}$mice have increased beta cell proliferation and improved glucose homeostasis Conditional $\beta-\mathrm{CB}_{1} \mathrm{R}^{-/}$mice were obtained by mating $C n r r^{\text {flox/flox }}$ with MIP-Cre/ERT mice (ESM Fig. 1). Six-week old $\beta-\mathrm{CB}_{1} \mathrm{R}^{-/}$and $\beta-\mathrm{CB}_{1} \mathrm{R}^{+/+}$mice were injected with tamoxifen for 5 days and monitored until
25 weeks of age (Fig. 1a-d). No difference in body weight (Fig. 1b) or body composition (ESM Fig. 2a-d) was observed between $\beta-\mathrm{CB} 1 \mathrm{R}^{+/+}$and $\beta-\mathrm{CB} 1 \mathrm{R}^{-/-}$mice. Fasting plasma insulin levels were significantly increased $(153 \pm 23 \%)$ by 10 weeks of age in $\beta-\mathrm{CB} 1 \mathrm{R}^{--}$mice compared with baseline and were significantly higher than in $\beta-\mathrm{CB}^{+/++}$(Fig. 1c) and MIP-Cre/ ERT mice (ESM Fig. 2e), which was reflected in lower fasting blood glucose (FBG) levels (Fig. 1d, ESM Fig. 2f). $\beta-\mathrm{CB}^{-/ R^{-/}}$ mice were more glucose tolerant than $\beta-\mathrm{CB}_{1} \mathrm{R}^{+/+}$mice in an IPGTT (Fig. 1e). After oral glucose-lipid challenge, $\beta-\mathrm{CB} \mathrm{R}^{-/}$ mice had higher circulating insulin levels than $\beta-\mathrm{CB} 1 \mathrm{R}^{+/+}$mice (Fig. 1f, ESM Fig. 2g). At 10 weeks, beta cell proliferation was 

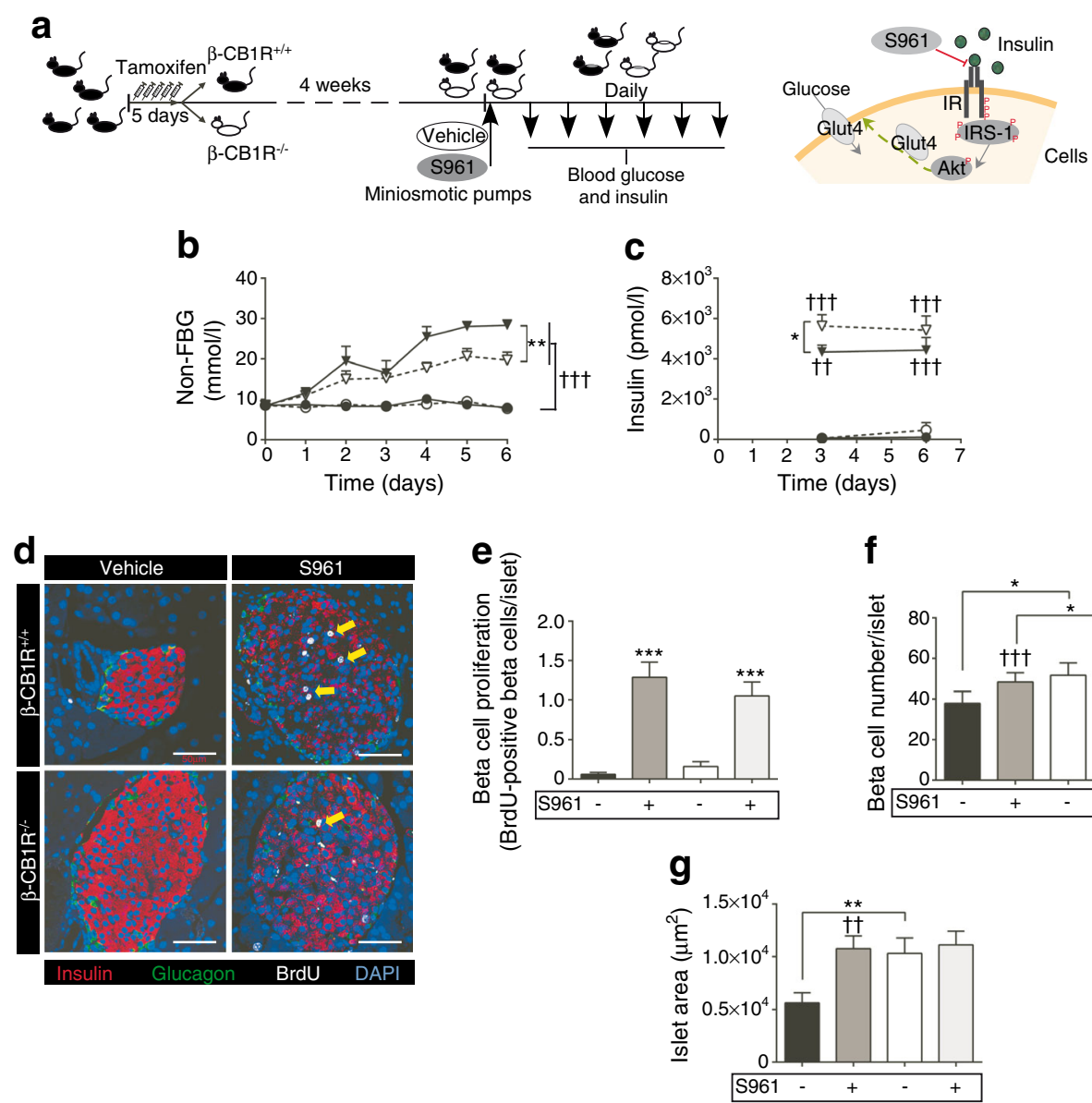

Fig. $2 \beta-\mathrm{CB} 1 \mathrm{R}^{-/-}$mice are more resistant to the hyperglycaemic effects of S961 than $\beta-\mathrm{CB} 1 \mathrm{R}^{+/+}$mice. (a) Schematic of the experimental design. Miniosmotic pumps containing vehicle or $10 \mathrm{nmol}$ S961 $(1.2 \mathrm{nmol} /$ day) were implanted subcutaneously in 10 - to 12 -week-old $\beta-\mathrm{CB} 1 \mathrm{R}^{+/+}$and $\beta-\mathrm{CB} 1 \mathrm{R}^{-/-}$mice 1 month after tamoxifen injections. (b) Non-FBG was measured daily and (c) plasma insulin levels were measured at days 3 and 6 after pump implantation. (d) Immunostaining for insulin (red), glucagon (green), BrdU (white; yellow arrows) and nuclei (DAPI; blue) of pancreases (scale bars, $50 \mu \mathrm{m}$ ). (e) Quantification of beta cell proliferation (BrdU-positive beta cells per

increased 5.6-fold in $\beta$-CB1 ${ }^{-/}$mice (Fig. 1g-i), and the islet area was significantly greater (1.9-fold) than in $\beta-\mathrm{CB} 1 \mathrm{R}^{+/+}$(Fig. 1j) and MIP-Cre/ERT (ESM Fig. 2h, i) mice, with no change in islet number (ESM Fig. 2j). Beta cell proliferation is regulated by insulin, cytokines and prolactin, which stimulate $I g f l$ expression in beta cells [27]. The trophic changes observed were independent of intra-islet IGF-1, since IgfI expression was decreased in $\beta-\mathrm{CB} 1 \mathrm{R}^{-/-}$compared with $\beta-\mathrm{CB} 1 \mathrm{R}^{+/+}$islets (Fig. 1k).

\section{CB1R ablation in beta cells reduced hyperglycaemia during} acute insulin resistance We examined whether $\beta-\mathrm{CB} 1 \mathrm{R}^{-/}$ mice would still respond to acute insulin resistance using S961, a competitive antagonist of the IR [28]. Ten-week-old $\beta-\mathrm{CB} 1 \mathrm{R}^{+/+}$and $\beta-\mathrm{CB} 1 \mathrm{R}^{-/-}$mice were implanted with miniosmotic pumps containing vehicle or S961. Glucose and insulin levels were followed daily for 6 days (Fig. 2a). By day islet), (f) beta cell number per islet and (g) islet area. $n=100$ islets/group. $n=8 \mathrm{~S} 961-\beta-\mathrm{CB} 1 \mathrm{R}^{+/+}, n=11 \mathrm{~S} 961-\beta-\mathrm{CB} 1 \mathrm{R}^{-/-}$mice, $n=9$ vehicle mice. Black circles/bars, $\beta-\mathrm{CB}_{1} \mathrm{R}^{+/+}$mice treated with vehicle; black triangles/dark grey bars, $\beta-\mathrm{CB}_{1 \mathrm{R}^{+/+}}$mice treated with $\mathrm{S} 961$; white circles/bars, $\beta-\mathrm{CB} 1 \mathrm{R}^{-/-}$mice treated with vehicle; white triangles/light grey bars, $\beta-\mathrm{CB} 1 \mathrm{R}^{-/-}$mice treated with S961. Data are means \pm SEM. Significance by $t$ test, $* p \leq 0.05, * * p \leq 0.01$, ***p 0.001 vs $\beta$ -

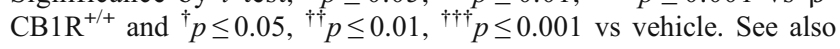
ESM Fig. 3

6, non-FBG was significantly lower in S961-treated $\beta-\mathrm{CB} 1 \mathrm{R}^{-1}$ mice $(19.7 \pm 1.9 \mathrm{mmol} / \mathrm{l})$ than in $\beta-\mathrm{CB} 1 \mathrm{R}^{+/+}(28.3 \pm$ $1.3 \mathrm{mmol} / \mathrm{l}$ ) (Fig. 2b) and MIP-Cre/ERT mice (ESM Fig. 3a). S961 treatment increased circulating insulin levels in $\beta$ $\mathrm{CB}^{+/ \mathrm{R}^{++}}$mice, but even more so in $\beta-\mathrm{CB}_{1} \mathrm{R}^{-/}$mice (Fig. 2c). By day 6, S961 had caused a 21-fold increase in beta cell proliferation per islet in $\beta-\mathrm{CB} 1 \mathrm{R}^{+/+}$mice compared with baseline, and to a lesser extent (6.5-fold) in $\beta-\mathrm{CB}_{1} \mathrm{R}^{-/-}$mice (Fig. $2 d$, e, ESM Fig. 3b). Increased beta cell proliferation in S961- $\beta$ $\mathrm{CB} 1 \mathrm{R}^{+/+}$mice resulted in increased beta cell number and larger islets (Fig. $2 \mathrm{f}, \mathrm{g}$ ). $\beta-\mathrm{CB} 1 \mathrm{R}^{-/-}$mice already had significantly more beta cells than $\beta-\mathrm{CB} 1 \mathrm{R}^{+++}$mice; a 6.5 -fold increase in proliferation in $\beta-\mathrm{CB} 1 \mathrm{R}^{-/}$mice was sufficient to further increase total beta cell numbers when mice were treated with S961 (Fig. 2f). Alpha cell numbers were comparable between strains; S961 treatment resulted in increased alpha cell numbers 
Fig. $3 \quad \beta-\mathrm{CB} 1 \mathrm{R}^{-/-}$mice become more obese than $\beta$ $\mathrm{CB}_{1} \mathrm{R}^{+/+}$mice when placed on an HFHS diet. (a) Schematic of the experimental design. Six- to 8week-old mice were injected with tamoxifen and 1 month later were standard diet (SD) for 15 weeks. (b) Body weight and (c) HFHS food intake. (d) Liver and epididymal (Ep) and s.c. adipose tissue (AT) were dissected and weighed at week 15. (e)

Respiratory exchange rate (RER) and (f) total physical activity ( $x$ axis activity as measured by CLAMS in mice on an HFHS diet. Black triangles, SD- $\beta$ $\mathrm{CB}_{1} \mathrm{R}^{+/+}$(not visible as covered by the white triangles in $\mathbf{b}$ ); black circles/bars, HFHS- $\beta-C B 1 R^{+/+}$; white triangles, SD- $\beta-\mathrm{CB} 1 \mathrm{R}^{-/-}$; white circles/bars, HFHS- $\beta$ $\mathrm{CB}_{1 \mathrm{R}^{-/-}} . n=7$ mice/group. Data are means \pm SEM. Significance by ANOVA or $t$ test, $* p \leq 0.05$, $* * * p \leq 0.001$ vs $\beta-\mathrm{CB} 1 \mathrm{R}^{+/+}$. See also ESM Fig. 4 placed on an HFHS diet or
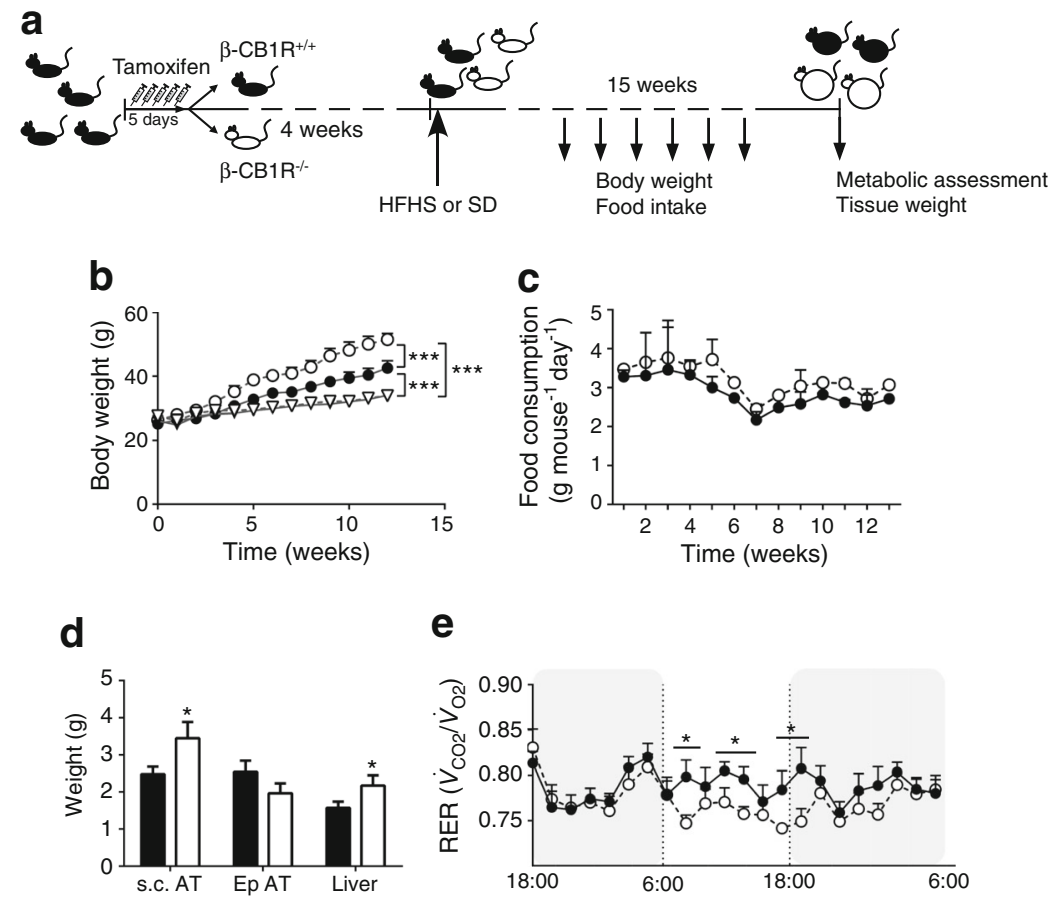

e
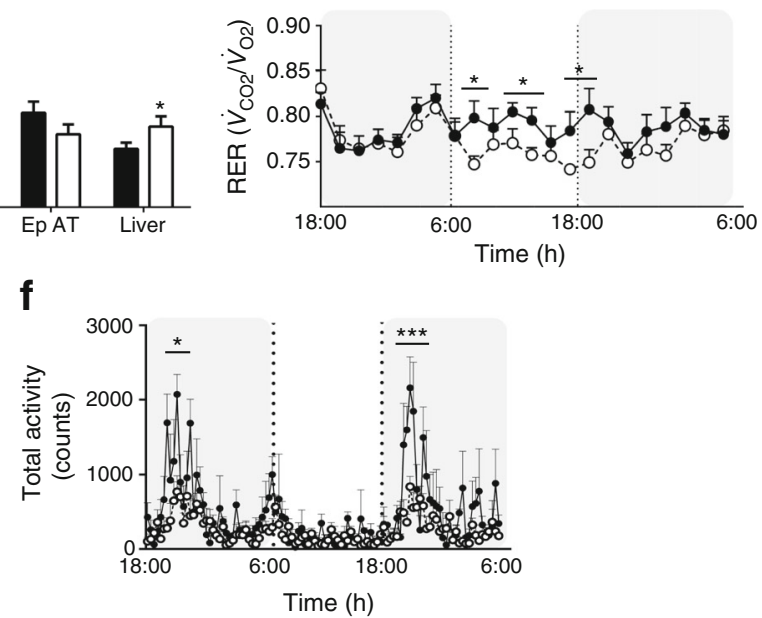

only in $\beta-C B 1 R^{+/+}$mice (ESM Fig. 3c). S961 treatment did not lead to a further increase in islet size in $\beta-\mathrm{CB} 1 \mathrm{R}^{-/}$mice compared with $\beta-\mathrm{CB} 1 \mathrm{R}^{+/+}$mice (Fig. $2 \mathrm{~g}$ ) because beta cell turnover was close to its maximum potential due to the absence of CB1R, and a further slight increase in proliferation did not significantly increase size. Beta cell apoptosis, as assessed by TUNEL staining (ESM Fig. 3d, e), and immune cell infiltration were not observed in or around islets (ESM Fig. 3f).

$\beta-C B 1 R^{-/-}$mice fed an HFHS diet gained more weight and became more glucose intolerant than $\beta-C B 1 R^{+/+}$mice $\beta$ $\mathrm{CB}_{1} \mathrm{R}^{+/+}$and $\beta-\mathrm{CB} 1 \mathrm{R}^{-/-}$mice, $10-12$ weeks old, were fed an HFHS diet (HFHS-mice) for 15 weeks (Fig. 3a) as a chronic stimulus for insulin secretion/production. $\beta-\mathrm{CB} 1 \mathrm{R}^{-1-}$ mice had similar body weight (35-36 g) to $\beta-\mathrm{CB} 1 \mathrm{R}^{+/+}$mice when fed a standard diet (SD-mice). However, HFHS- $\beta-\mathrm{CB} 1 \mathrm{R}^{-/}$mice gained $21 \pm 4 \%$ more weight than HFHS- $\beta-\mathrm{CB} 1 \mathrm{R}^{+/+}$and MIPCre/ERT mice (Fig. 3b, ESM Fig. 4), with comparable food intake (Fig. 3c). This phenotype is distinct from the global $\mathrm{CB} 1 \mathrm{KO}$ mouse phenotype, with the latter weighing less than SD- or HFHS-fed $\beta-\mathrm{CB} 1 \mathrm{R}^{+/+}$and $\beta-\mathrm{CB} 1 \mathrm{R}^{-/}$mice (ESM Fig. $5 a$ ), demonstrating that this effect is specific to $\mathrm{CB} 1 \mathrm{R}$ ablation in beta cells. Liver and subcutaneous adipose tissue from HFHS- $\beta$ $\mathrm{CB}_{1 \mathrm{R}}{ }^{-/}$mice weighed significantly more than that from control littermates (Fig. 3d), while CB1KO mouse liver and subcutaneous adipose tissue weighed less than that from control littermates (ESM Fig. $5 b$ ). HFHS- $\beta-C B 1 \mathrm{R}^{+/+}$mice had a higher respiratory exchange rate (RER) during daylight compared with HFHS- $\beta$ $\mathrm{CB}^{-1 /}$ mice $(0.79 \pm 0.01$ vs $0.74 \pm 0.01)$ (Fig. 3e). RER, the ratio of carbon dioxide production/oxygen consumption, estimates the fuel source since glucose metabolism requires more oxygen than fat [29]. At night-time the fuel source is the consumed food. The lower RER in HFHS- $\beta-\mathrm{CB} 1 \mathrm{R}^{--}$mice during daylight reflects increased fat utilisation because of differences in fat depots. HFHS- $\beta-\mathrm{CB} 1 \mathrm{R}^{--}$mice had lower activity during the night (active cycle) than HFHS- $\beta-\mathrm{CB} 1 \mathrm{R}^{+/+}$mice (Fig. $3 \mathrm{f}$ ). HFHS- $\beta-\mathrm{CB}_{1} \mathrm{R}^{-/-}$mice became more insulin intolerant, as demonstrated by higher FBG (Fig. 4a) and fasting plasma insulin (Fig. 4b) levels than HFHS- $\beta-\mathrm{CB} 1 \mathrm{R}^{+/+}$mice. Liver IRS-2 protein levels, an indicator of insulin resistance [30], were lower in HFHS- $\beta-C B 1 R^{+/+}$compared with SD- $\beta-C B 1 R^{+/+}$mice (Fig. 4c, ESM Fig. $5 c)$. SD- $\beta-C B 1 R^{-1-}$ mice had lower liver IRS-2 levels than SD- $\beta-C B 1 R^{+/+}$mice, which were unchanged on an HFHS $\operatorname{diet}$ (Fig. 4c, ESM Fig. 5c). This suggests that even on a standard 
Fig. $4 \quad \beta-\mathrm{CB} 1 \mathrm{R}^{-/-}$mice become more insulin resistant than $\beta-\mathrm{CB} 1 \mathrm{R}^{+/+}$mice when placed on an HFHS diet. (a) FBG and (b) fasting plasma insulin levels. (c) Western blot analysis of IRS-2 immunoprecipitated from liver extracts and graph of band density analysed by ImageJ. (d, e) IPGTT and (f, g) OGTT $(1.5 \mathrm{~g} / \mathrm{kg}$ glucose) (d, f blood glucose over time and AUC; e, g plasma insulin over time). Stimulated (h) GLP-1 and (i) GIP levels in plasma upon oral glucose-lipid challenge (20 min). $n=7$ mice. Dark grey bar, SD- $\beta-\mathrm{CB} 1 \mathrm{R}^{+/+}$; black circles/bars, HFHS- $\beta$ $\mathrm{CB}_{1} \mathrm{R}^{+/+}$; light grey bar, SD- $\beta$ $\mathrm{CB} 1 \mathrm{R}^{-/-}$; white circles/bars, HFHS- $\beta-C B 1 R^{-/-}$. Data are means \pm SEM. Significance by ANOVA or $t$ test, ${ }^{*} p \leq 0.05$, $* * p \leq 0.01$ vs $\beta-\mathrm{CB} 1 \mathrm{R}^{+/+} ;{ }^{\dagger \dagger} p \leq$ 0.001 vs standard diet. See also ESM Fig. 5 a

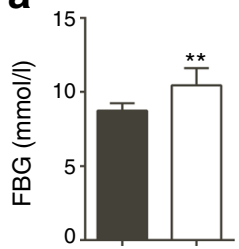

b

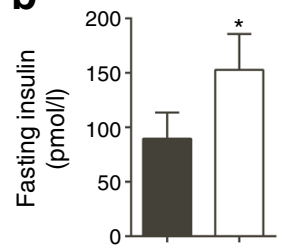

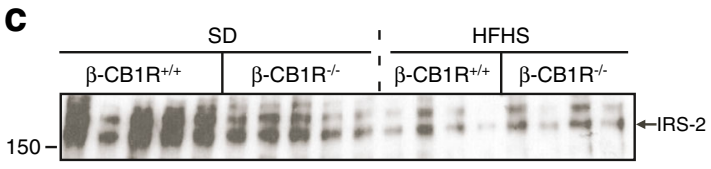

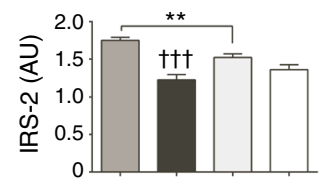

d

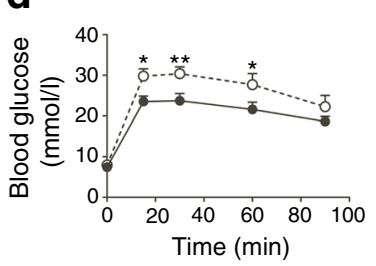

f

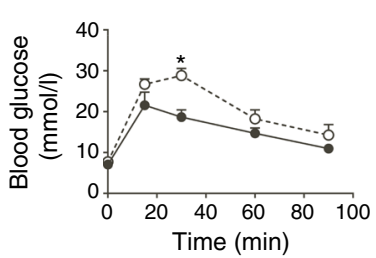

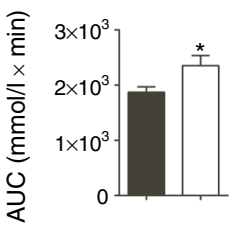

e

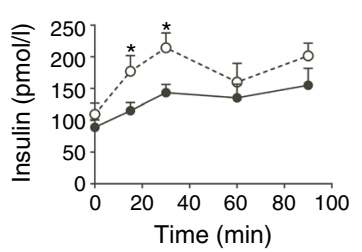

g

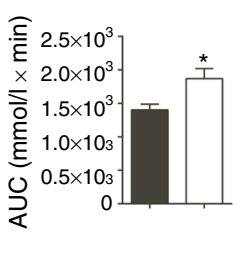

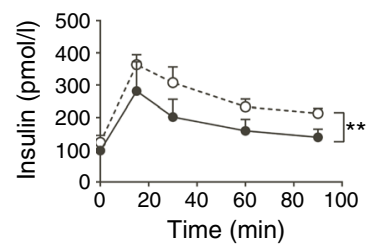

h

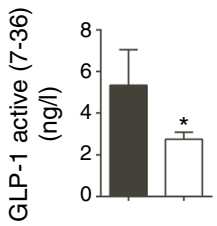

i

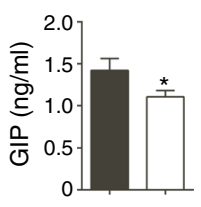

diet, insulin resistance occurs in the livers of $\beta-\mathrm{CB} 1 \mathrm{R}^{-/-}$mice, probably as an adaptation to mitigate hypoglycaemia. IR phosphorylation was also decreased in HFHS- $\beta-\mathrm{CB} 1 \mathrm{R}^{-/}$mice compared with HFHS- $\beta$-CB1 $\mathrm{R}^{+/+}$mice (ESM Fig. $5 \mathrm{~d}$ ). Blockade of $\mathrm{CB} 1 \mathrm{R}$ in the liver alleviates diet-induced insulin resistance by increasing insulin sensitivity [12]. To determine whether acute pharmacological inhibition of peripheral CB1R (i.e. liver and/or muscle) could alleviate insulin resistance in HFHS- $\beta-\mathrm{CB} 1 \mathrm{R}^{-/}$ mice, we administered the peripherally restricted CB1R antagonist JD-5037 [19] i.p. 30 min before an ITT. JD-5037 increased insulin sensitivity in HFHS- $\beta-C B 1 R^{+/+}$mice (ESM Fig. 5e), and more so in the insulin-intolerant HFHS- $\beta-\mathrm{CB} 1 \mathrm{R}^{-/}$mice (ESM Fig. 5f). During an IPGTT, HFHS- $\beta-C B 1 \mathrm{R}^{-/-}$mice had higher blood glucose than HFHS- $\beta-C B 1 R^{+/+}$mice, probably because of increased insulin resistance (Fig. 4d). Interestingly, early insulin secretion was protected in HFHS- $\beta-C B 1 \mathrm{R}^{-/-}$mice (Fig. 4e). Similar results were obtained during an OGTT (Fig. 4f, g). Stimulated GLP-1 and GIP plasma levels were significantly lower in HFHS- $\beta-C B 1 \mathrm{R}^{-/}$compared with HFHS- $\beta-C B 1 \mathrm{R}^{+/+}$ mice 20 min after glucose-lipid challenge (Fig. 4h, i), which probably indicates a homeostatic negative feedback response to prevent hyperinsulinaemia.

CB1R ablation in beta cells leads to enhanced function in isolated islets To study the enhanced beta cell function observed in $\beta-\mathrm{CB} 1 \mathrm{R}^{-/-}$mice, we isolated islets for ex vivo analysis (Fig. 5a). $\beta$-CB1 $\mathrm{R}^{-/}$islets were visually bigger than those from $\beta-\mathrm{CB} 1 \mathrm{R}^{+/+}$mice (Fig. $5 \mathrm{~b}$ ), consistent with in situ measurements (Fig. 1j). CB1R is constitutively active under nonstimulated conditions, and thus inverse agonists or genetic ablation should eliminate basal activity [31]. Non-stimulated, resting intracellular cAMP levels (Fig. 5c) and insulin secretion (Fig. 5d) were increased in $\beta-\mathrm{CB} 1 \mathrm{R}^{-/-}$compared with $\beta$ $\mathrm{CB} \mathrm{R}^{+/+}$islets $(217 \pm 33 \%$ and $175 \pm 10 \%$, respectively). Ex4-stimulated AC activity resulted in a $391 \pm 9 \%$ increase in cAMP levels in $\beta-\mathrm{CB} 1 \mathrm{R}^{-/}$islets compared with $176 \pm 4 \%$ in 
a

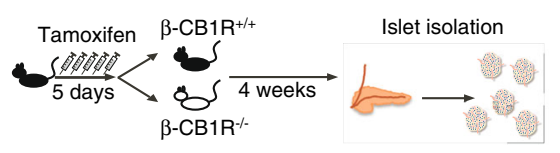

b

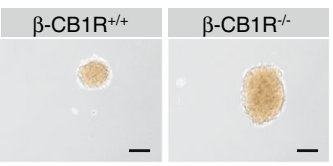

C

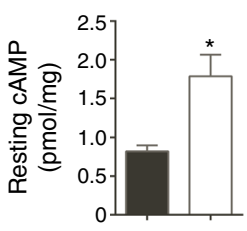

f

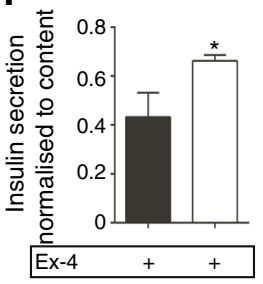

h

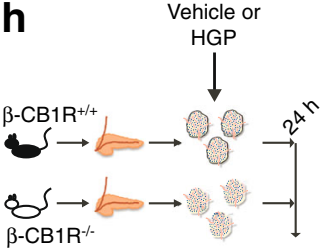

Viability

cAMP quantification

Fig. 5 Pancreatic islets from $\beta-\mathrm{CB} 1 \mathrm{R}^{-/-}$mice secrete more insulin and are protected from HGP stress ex vivo. (a) Schematic of the experimental design. Pancreatic islets were isolated from $\beta-\mathrm{CB} 1 \mathrm{R}^{+/+}$and $\beta-\mathrm{CB} 1 \mathrm{R}^{-/-}$ mice 1 month after tamoxifen injections. (b) Representative images of islets (scale bars, $100 \mu \mathrm{m}$ ). (c) Resting intra-islet cAMP and (d) insulin secretion were quantified under non-stimulatory conditions $(2 \mathrm{mmol} / \mathrm{l}$ glucose). (e) Islets $(n=40)$ were stimulated in vitro with $0.33 \mathrm{nmol} / \mathrm{l}$ Ex-4 in the presence of IBMX and $7.5 \mathrm{mmol}$ glucose, and intra-islet cAMP was quantified. (f) Ex-4-mediated glucose-dependent insulin secretion from freshly isolated islets. (g) Glucose-stimulated insulin

$\beta-C B 1 R^{+/+}$islets (Fig. 5e). Ex-4-stimulated glucosemediated insulin secretion was also significantly higher in $\beta-\mathrm{CB} 1 \mathrm{R}^{-/-}$compared with control islets (Fig. 5f). Islets were placed in a perifusion system [8] to examine glucose-stimulated insulin secretion (Fig. $5 \mathrm{~g}$ ). $\beta$-CB1 $\mathrm{R}^{-/-}$ islets had increased insulin secretion, an earlier peak of the first phase and greater AUC for insulin than $\beta-C B 1 \mathrm{R}^{+/+}$ islets (Fig. 5g), all likely resulting from increased $\mathrm{AC}$ activity (Fig. 5c). Similar results were found in CB1KO islets (ESM Fig. 6a). To mimic diet-induced beta cell damage, we cultured isolated islets with or without high glucose and palmitate (HGP) for $24 \mathrm{~h}$ (Fig. 5h). Loss of viability as seen in $\mathrm{HGP}-\beta-\mathrm{CB} 1 \mathrm{R}^{+/+}$islets was not observed in HGP- $\beta-C B 1 R^{-/-}$islets (Fig. $5 \mathrm{i}$ ). HGP- $\beta-\mathrm{CB} 1 \mathrm{R}^{-/-}$islets also had higher intracellular cAMP levels (required for secretion from perifused $\beta-\mathrm{CB} 1 \mathrm{R}^{+/+}$and $\beta-\mathrm{CB} 1 \mathrm{R}^{-/-}$islets with $\mathrm{AUC}$ ( $n=100$ islets; $n=4$ mice). (h) Schematic of the experimental design. Islets isolated from $\beta-\mathrm{CB} 1 \mathrm{R}^{+/+}$and $\beta-\mathrm{CB} 1 \mathrm{R}^{-/-}$mice were incubated with HGP (glucose $16.5 \mathrm{mmol} / \mathrm{l}$, palmitate $500 \mu \mathrm{mol} / \mathrm{l}$ ) for $24 \mathrm{~h}$. (i) Viability of HGP-treated islets (the dotted line represents the vehicle control [Veh.]). RFU, relative fluorescence units. (j) Intra-islet cAMP levels after treatment with HGP. Black circles/bars, $\beta-\mathrm{CB} 1 \mathrm{R}^{+/+}$; white circles/bars, $\beta$ $\mathrm{CB}_{1} \mathrm{R}^{-/-} . n=7$ mice; $n=3$ independent experiments with $n=40-50$ islets. Data are means \pm SEM. Significance by $t$ test, $* p \leq 0.05$, $* * x \leq 0.01$, $* * * p \leq 0.001$ vs $\beta-\mathrm{CB}_{1 \mathrm{R}}{ }^{+/+} ;{ }^{\dagger} p \leq 0.05,{ }^{\dagger \dagger} p \leq 0.001$ vs vehicle

maximal insulin secretion) than control littermates, reflecting increased beta cell functional capacity (Fig. 5j).

CB1R ablation in beta cells leads to a metabolic shift and reduces ROS production $\mathrm{CB} 1 \mathrm{R}$ impacts mitochondrial metabolism in muscle and neurons [32,33], and ATP generation via glucose metabolism is required for insulin secretion [34]. We analysed mitochondrial metabolism in $\beta-\mathrm{CB} 1 \mathrm{R}^{-/}$islets by measuring the OCR and ECAR (Fig. 6a-c). Islets were preincubated for $1 \mathrm{~h}$ in $2 \mathrm{mmol} / \mathrm{l}$ glucose; the addition of $16.5 \mathrm{mmol} / \mathrm{l}$ glucose increased mitochondrial respiration (oligomycin-inhibited $\triangle \mathrm{OCR}$ ) by $185 \pm 8 \%$ in $\beta-\mathrm{CB} 1 \mathrm{R}^{+/+}$islets, and to a lesser extent $(158 \pm 9 \%)$ in $\beta-\mathrm{CB} 1 \mathrm{R}^{-/}$islets (Fig. 6b, ESM Fig. 6b). The OCR was inhibited by oligomycin in both strains, indicating that the oxygen consumption was due to 

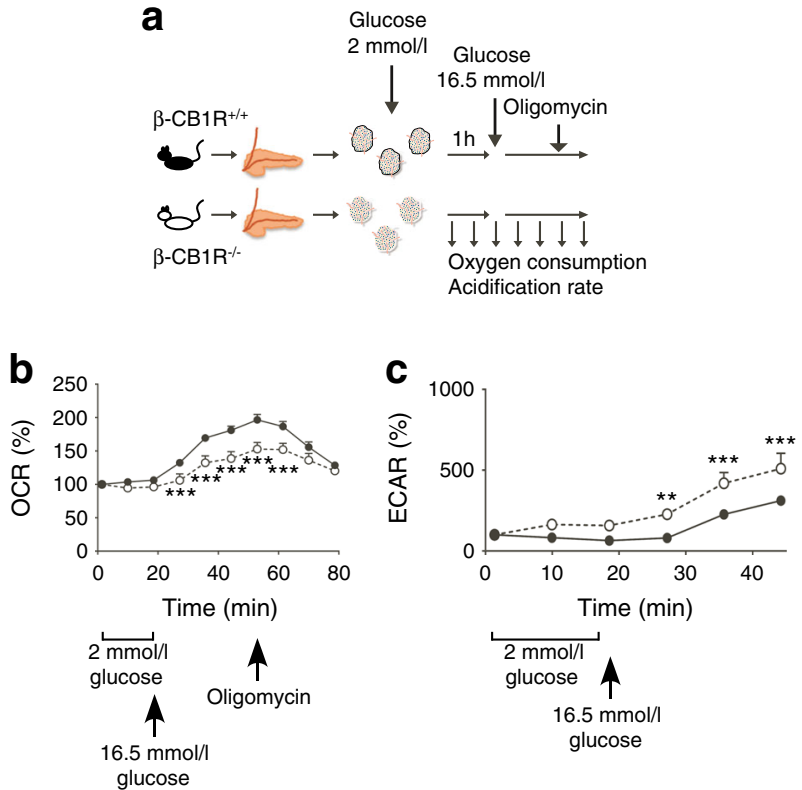

glucose

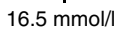

glucose
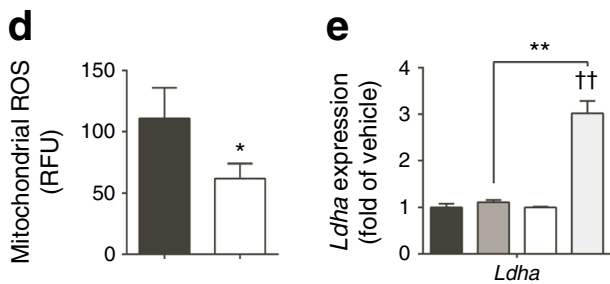

Fig. $6 \quad \beta-\mathrm{CB} 1 \mathrm{R}^{-/-}$islets have a metabolic shift and produce fewer ROS. (a) Schematic of the experimental design. Pancreatic islets were isolated from $\beta-\mathrm{CB} 1 \mathrm{R}^{+/+}$and $\beta-\mathrm{CB} 1 \mathrm{R}^{-/-}$mice a month after tamoxifen injections. Freshly isolated islets $(n=30)$ were incubated in $2 \mathrm{mmol} / \mathrm{l}$ glucose and (b) the OCR and (c) ECAR were measured using Seahorse Technology when stimulated with $16.5 \mathrm{mmol} / 1$ glucose. $n=30$ islets, $n=$ 6-8 replicates. Black circles, $\beta-\mathrm{CB} 1 \mathrm{R}^{+/+}$; white circles, $\beta-\mathrm{CB} 1 \mathrm{R}^{-/-}$. (d) Mitochondrial production of ROS in freshly isolated islets. RFU, relative fluorescence units. (e) Relative mRNA expression of Ldha in HGP-treated $\beta-\mathrm{CB} 1 \mathrm{R}^{+/+}$(black bar, vehicle; dark grey bar, $\mathrm{HGP}$ ) and $\beta-\mathrm{CB} 1 \mathrm{R}^{-/-}$ (white bar, vehicle; light grey bar, HGP) islets. $n=3$ independent experiments with $n=30-50$ islets. Data are means \pm SEM. Significance by $t$ test, $* p \leq 0.05, * * p \leq 0.01, * * * p \leq 0.001$ vs $\beta-\mathrm{CB}^{*} \mathrm{R}^{+++} ;{ }^{\dagger \dagger} p \leq 0.01$ vs vehicle. See also ESM Fig. 6

mitochondrial respiration. The basal ECAR (an indicator of lactate production) was equal in both strains, and the addition of glucose significantly increased the ECAR in $\beta-\mathrm{CB} 1 \mathrm{R}^{-/-}$ islets compared with $\beta-\mathrm{CB} 1 \mathrm{R}^{+/+}$islets $(509 \pm 94 \%$ vs $311 \pm$ 28\%; Fig. 6c). Mitochondria are the primary source of ROS, and a high respiration rate is associated with ROS production [35]. Islets from fasted $\beta-\mathrm{CB} 1 \mathrm{R}^{-/}$mice had significantly lower ROS production compared with $\beta-\mathrm{CB} 1 \mathrm{R}^{+/+}$mice (Fig. $6 \mathrm{~d}$ ). $L d h a$ expression significantly increased only in HGP- $\beta$ $\mathrm{CB} 1 \mathrm{R}^{-/-}$islets (Fig. 6e), in concordance with the ECAR data.

\section{CB1R ablation in beta cells protects islets from metabolic} stress and inflammation Obesity-related molecules such as ROS, ceramides, palmitate and elevated circulating glucose activate the NLRP3 (NLR family, pyrin domain containing 3) inflammasome through phosphorylation of NFKB p65, leading to immune cell infiltration [36-41]. ROS activates NLRP3 by inducing a direct interaction with TXNIP [36-38]. HFHS- $\beta$ $\mathrm{CB}^{-/ \mathrm{R}^{-/}}$mice (Fig. 7a) had lower intra-islet levels of TXNIP and ceramide than HFHS- $\beta-C B 1 R^{+/+}$mice (Fig. $7 b$ ). Intra-islet levels of p-p65 were significantly higher in HFHS- $\beta-C B 1 R^{+/+}$ compared with HFHS- $\beta-\mathrm{CB} 1 \mathrm{R}^{-/}$mice (Fig. $7 \mathrm{~b}$ ). Infiltrating cells, such as T cells $\left(\mathrm{CD}^{+}\right)$and macrophages $\left(\mathrm{CD} 68^{+}\right)$, were observed in close proximity to blood vessels, and in and around the islets of HFHS- $\beta$-CB1R ${ }^{+/+}$mice (yellow arrows, Fig. $7 b$, c, ESM Fig. 7a). Flow cytometry analysis showed that the T cells were $\mathrm{CD}^{+} 9^{+}$(ESM Fig. 7a). Such infiltration was absent in $\beta$ $\mathrm{CB}^{-/ \mathrm{R}^{--}}$mice fed an HFHS diet for 15 weeks (Fig. 7a, c, ESM Fig. 7b). Circulating EC levels remained unchanged (ESM Fig. 7c) and intra-islet $C n r 2$ expression was significantly lower (ESM Fig. 7d) in $\beta$-CB1 ${ }^{-/}$mice; there was no compensation by the cannabinoid 2 receptor $(\mathrm{CB} 2 \mathrm{R})$, the main $\mathrm{EC}$ receptor in immune cells, or activation of CB1R in other islet cell types that explained the reduced immune cell infiltration. $\beta-\mathrm{CB} 1 \mathrm{R}^{-/-}$islets had lower Illb, Nlrp3 and Tnfa expression than $\beta-\mathrm{CB} 1 \mathrm{R}^{+/+}$islets (Fig. 7df). Microarray analysis confirmed a downregulation of CB1R, TXNIP, NFKB, TNF- $\alpha$ and IL- $1 \beta$ pathways in $\beta-\mathrm{CB}_{1} \mathrm{R}^{-/}$relative to $\beta-\mathrm{CB} \mathrm{R}^{+/+}$islets (ESM Fig. 7e). Tnfa expression was increased only in HGP- $\beta-\mathrm{CB} 1 \mathrm{R}^{+++}$but not in HGP- $\beta-\mathrm{CB} 1 \mathrm{R}^{-/-}$ islets (Fig. $7 \mathrm{~g}, \mathrm{~h}$ ). Although $I l 1 b$ expression was increased in HGP- $\beta-C B 1 R^{--}$islets (Fig. $7 \mathrm{~h}$ ), it was significantly less than in HGP- $\beta-C B 1 R^{+/+}$mice. Secretion of IL- $1 \beta$ and TNF- $\alpha$ from HGP- $\beta-C B 1 R^{-/}$was significantly reduced or undetectable, respectively, compared with HGP- $\beta-C B 1 R^{+/+}$islets (Fig. 7i, j). Activation of JNK and p38, as happens with proinflammatory cytokines such as IL-1 $\beta$ and TNF- $\alpha$, leads to beta cell death [ $[42$, 43] and EC-mediated cytokine secretion from macrophages [18]. HGP- $\beta$-CB1 $\mathrm{R}^{-/}$islets had significantly lower levels of $\mathrm{p}$-p38 than $\beta-\mathrm{CB} 1 \mathrm{R}^{+/+}$islets, while $\mathrm{p}$-Erk1/2 or $\mathrm{p}$-SAPK/JNK did not change (Fig. 7k). Downstream signalling of p38 was also reduced (p-p53, p-Stat1 and p-HSP27), together with reduced cleaved-caspase 3 and cleaved-PARP (Fig. 7k), indicating reduced cytokine-induced apoptosis [44]. To investigate if lower MAPK activation was due to lower cytokine secretion or sensitivity, islets were treated ex vivo with mixtures of cytokines (IL$1 \beta$, TNF- $\alpha$ and IFN- $\gamma$ [45]) for $18 \mathrm{~h}$ (Fig. 71 ). $\beta-\mathrm{CB} 1 \mathrm{R}^{-/}$islets had significantly lower levels of cytotoxicity than $\beta-C B 1 R^{+/+}$ islets, with levels never reaching above those of vehicle-treated $\beta-{ }_{-C B 1 R^{+/+}}$islets (Fig. $7 \mathrm{~m}$ ). These data show that $\beta-\mathrm{CB}_{1} \mathrm{R}^{-/}$ islets have lower basal cytotoxicity and, while responsive to cytokines, lower cytokine secretion lessens the inflammatory cascade protecting the islet.

\section{Discussion}

Our study describes the role of CB1R specifically in pancreatic beta cells and its relevance to whole-animal physiology. By 

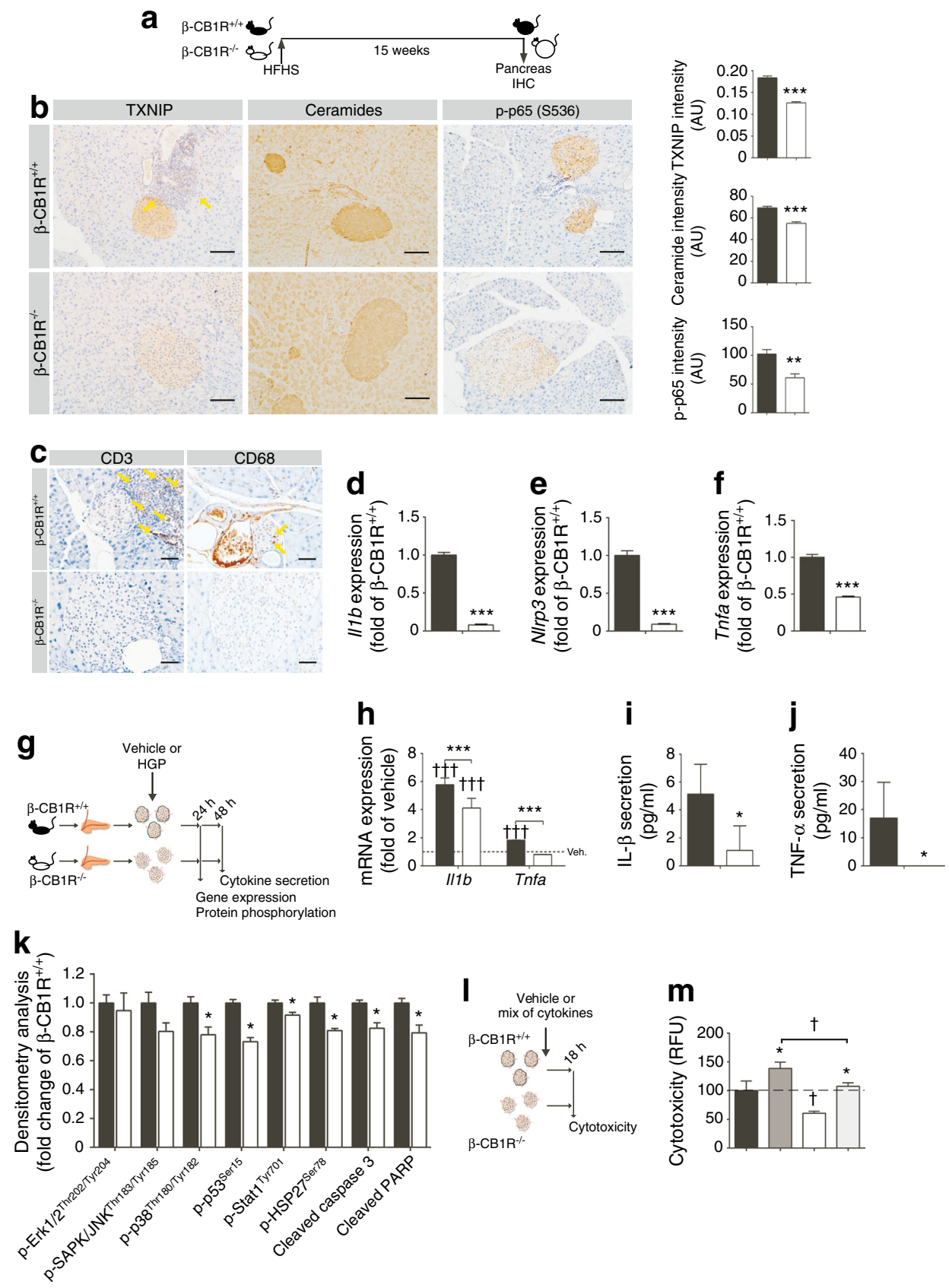

Fig. 7 Ablation of CB1R protects islets from HFHS diet-induced inflammation. (a) Schematic of the experimental design. $\beta-C B 1 R^{+/+}$and $\beta-$ $\mathrm{CB}_{1} \mathrm{R}^{-/-}$mice were fed an HFHS diet for 15 weeks, after which the mice were euthanised and pancreases were dissected and processed for immunohistochemistry (IHC) and stained. (b) Immunostaining for TXNIP, ceramides and $\mathrm{p}$-p65 of pancreases from $\beta-\mathrm{CB} 1 \mathrm{R}^{+/+}$and $\beta-\mathrm{CB} 1 \mathrm{R}^{-/-}$ mice fed an HFHS diet for 15 weeks (scale bars, $100 \mu \mathrm{m}$ ) and their quantification. (c) Immunostaining for $\mathrm{CD} 3$ and $\mathrm{CD} 68$ in pancreases from $\beta-\mathrm{CB} 1 \mathrm{R}^{+/+}$and $\beta-\mathrm{CB} 1 \mathrm{R}^{-/-}$mice fed an HFHS diet (scale bars, $50 \mu \mathrm{m})$. The yellow arrows point to areas of immune cell infiltrate between a blood vessel and islet, and into the islet. (d-f) Relative mRNA expression of inflammatory markers in freshly isolated islets. (g) Schematic of the experimental design. Islets isolated from $\beta-\mathrm{CB} 1 \mathrm{R}^{+/+}$ and $\beta-\mathrm{CB} 1 \mathrm{R}^{-/-}$mice were treated with HGP (glucose $16.5 \mathrm{mmol} / \mathrm{l}$, palmitate $500 \mu \mathrm{mol} / 1$ ) or vehicle. (h) Relative mRNA expression of

inflammatory markers (the dotted line represents the vehicle control). (i, j) Secretion of inflammatory markers. (k) Densitometry of phosphorylated proteins and cleaved proteins from isolated islets treated with HGP. $n=7$ mice; $n=3$ independent experiments with $n=30-50$ islets. Black bars, $\beta-\mathrm{CB} 1 \mathrm{R}^{+/+}$; white bars, $\beta-\mathrm{CB} 1 \mathrm{R}^{-/-}$. (l) Schematic of the experimental design. Islets isolated from $\beta-\mathrm{CB} 1 \mathrm{R}^{+/+}$and $\beta-\mathrm{CB} 1 \mathrm{R}^{-/-}$mice were treated with vehicle or a mixture of cytokines for $18 \mathrm{~h}$. (m) Cytotoxicity of vehicle- or cytokine-treated islets. RFU, relative fluorescence units. Black, $\beta-\mathrm{CB} 1 \mathrm{R}^{+/+}$mice treated with vehicle; dark grey, $\beta-\mathrm{CB} 1 \mathrm{R}^{+/+}$mice treated with cytokines; white, $\beta-\mathrm{CB} 1 \mathrm{R}^{-/-}$mice treated with vehicle; light grey, $\beta-\mathrm{CB} 1 \mathrm{R}^{-/-}$mice treated with cytokines. $n=4$ mice; $n=4$ replicates; $n=15$ islets. Data are means \pm SEM. Significance by $t$ test or ANOVA $* p \leq 0.05, * * p \leq 0.01, * * * p \leq 0.001$ vs $\beta-\mathrm{CB}^{*} \mathrm{R}^{+/+} ;{ }^{\dagger} p \leq 0.05,{ }^{\dagger \dagger} p \leq$ 0.001 vs vehicle. See also ESM Fig. 7 
genetically ablating CB1R in adult beta cells, we conclude that $\mathrm{CB} 1 \mathrm{R}$ is a negative regulator of beta cell function, proliferation and viability, and is a key component of the inflammatory response of islets. ECs orchestrate the organisation of pancreatic islets in perinatal development [46]. Ablating CB1R in adult mice avoids potential alterations in islet structure. Previous reports related to the ECS in beta cells have been conflicting due to the influence of CB1R in other tissues involved in glucose homeostasis and off-target effects of pharmacological approaches; other non-CB1R cannabinoid receptors have been described in islets $[5,47]$. While whole-body genetic or pharmacological CB1R blockade has been reported to result in increased insulin secretion [4, 24], enhanced beta cell function may be a consequence of reduced insulin resistance in liver and muscle $[10,11]$, producing a favourable environment for beta cells. Our model definitively describes the importance of CB1R in beta cell biology and function by eliminating these confounding factors and, for the first time, describes the direct effects of CB1R on beta cell mitochondria. CB1R ablation in beta cells resulted in a metabolic shift towards reduced mitochondrial respiration that protected islets from oxidative stress and improved beta cell functional capacity. Unexpectedly, ablation of CB1R in beta cells was sufficient to prevent the inflammatory response in islets under the metabolic stress of an HFHS diet.

Ablation of CB1R, a constitutively active $\mathrm{G}_{\alpha i}$ proteincoupled receptor and $\mathrm{AC}$ inhibitor, resulted in increased intrabeta cell cAMP and earlier onset of in vivo and ex vivo insulin secretion. We propose that increased insulin secretion led to increased levels of circulating insulin in $\beta-\mathrm{CB} 1 \mathrm{R}^{-/}$mice, eventually resulting in insulin resistance. Isolated $\beta-\mathrm{CB}^{-1-} \mathrm{R}^{-/}$islets confirmed increased insulin secretion as a primary event, and our mouse model provides insight into the response of the whole body to primary hyperinsulinaemia. Excessive unremitting insulin secretion due to a primary beta cell event, such as overexpression of the Ins gene or chronic exogenous administration of insulin, results in insulin resistance in the liver, weight gain, increased adiposity, ectopic adipose deposition and loss of the ability to increase glucose-stimulated insulin secretion [48, 49]. Primary hyperinsulinaemia with normal blood glucose levels occurs with inactivating mutations of the SUR1 subunit of the $\mathrm{K}^{+}$-ATP channel in mice; however, these mice lose their glucose-stimulated insulin secretion capacity time [50]. Therefore, insulin resistance in HFHS- $\beta-\mathrm{CB} 1 \mathrm{R}^{-/-}$mice is probably a homeostatic response to prevent hypoglycaemia. However, unlike in previous genetic models of primary hyperinsulinaemia, beta cell dysfunction was not observed in HFHS- $\beta-\mathrm{CB} 1 \mathrm{R}^{--}$mice. This is due to a myriad of beneficial intracellular events, an increased beta cell number and a reduced intracellular inflammatory environment. These data underline the potential of CB1R blockade as a treatment for type 2 diabetes compared with classic treatments that elevate insulin secretion, such as sulfonylureas, which do not integrate other signals in beta cells.
An HFHS diet led to greater weight gain in $\beta-\mathrm{CB} 1 \mathrm{R}^{-/-}$ mice. SD- or HFHS-CB1KO mice do not gain weight due to reduced food intake because of CB1R ablation in the brain $[51,52]$. Chronic hyperinsulinaemia per se may drive fat deposition in HFHS- $\beta-\mathrm{CB} 1 \mathrm{R}^{-/-}$mice as it stimulates insulin signalling in white adipose tissue and increases body weight $[49,53,54]$. This is substantiated by our observation that HFHS- $\beta-\mathrm{CB} 1 \mathrm{R}^{-/-}$mice had a lower RER and decreased activity relative to HFHS- $\beta$-CB1 $\mathrm{R}^{+/+}$mice, resulting in less glucose uptake by muscle and increased fat deposition. A lower RER in HFHS- $\beta-\mathrm{CB} 1 \mathrm{R}^{-/-}$mice during daylight probably indicates that the two strains are not using the same stored fuel source. HFHS- $\beta-\mathrm{CB} 1 \mathrm{R}^{--}$mice have more subcutaneous adipose tissue, which may alter the 'accessibility' to fuel in the resting state compared with HFHS- $\beta-\mathrm{CB} 1 \mathrm{R}^{+/+}$mice.

Recently, CB1R was found in the mitochondrial membranes of neurons and muscle [32, 33], but its role in mitochondria has not been described in beta cells. Some reports have indicated that CB1R activation decreases mitochondrial respiration [55] while others have reported the opposite [32]. We found a reduction in mitochondrial respiration in $\beta-\mathrm{CB} 1 \mathrm{R}^{-/-}$islets and increased $L d h a$ expression under the metabolically stressful condition of HGP. Decreased mitochondrial respiration possibly results from nullifying CB1R in beta cell plasma membranes. This could be the result of two effects: increased intracellular cAMP that induces $L d h a$ expression [56] and/or increased efficiency of insulin secretion that requires less mitochondrial activation. Regardless, the reduction in mitochondrial respiration led to reduced ROS, thereby probably preventing oxidative stress damage.

Ablating CB1R in beta cells of adult mice unexpectedly reduced the inflammatory environment in islets. While CB2R is a known immune modulator, it was recently reported that CB1R plays a role in the inflammatory process in the pancreas of a model of type 2 diabetes. Inhibiting $\mathrm{Cnrl}$ expression using small interfering RNA specifically in macrophages or comprehensive peripheral CB1R blockade by JD-5037 led to reduced activation of the NLRP3 inflammasome in macrophages, and reduced immune infiltration in leptin receptor-deficient Zucker diabetic fatty rat islets [22]. The authors did not implicate CB1R in beta cells as a factor in macrophage-mediated beta cell failure. We now know that CB1R in beta cells is necessary for HFHS-induced inflammation in and around mouse islets. The differing results could be attributed to CB1R ablation in different tissues (macrophages vs beta cells), different stressors (rats fed a standard diet vs mice fed an HFHS diet to more closely mimic the Western diet) and normally functioning leptin receptors present in $\beta-\mathrm{CB}^{-1 /}{ }^{-/}$mice. $\beta-\mathrm{CB} 1 \mathrm{R}^{-/-}$islets had significantly lower basal expression and lower secretion of proinflammatory cytokines than $\beta-\mathrm{CB} 1 \mathrm{R}^{+/+}$ islets, and reduced activation of $\mathrm{p} 38$ compared with $\beta-\mathrm{CB} \mathrm{R}^{+/+}$ islets, which, similar to NFKB, is downstream of IL- $1 \beta$ signalling. A reduction in MAPK activation would further reduce caspase cleavage and activation of proinflammatory transcription factors (Fig. 8). The NLRP3 inflammasome is inhibited by 


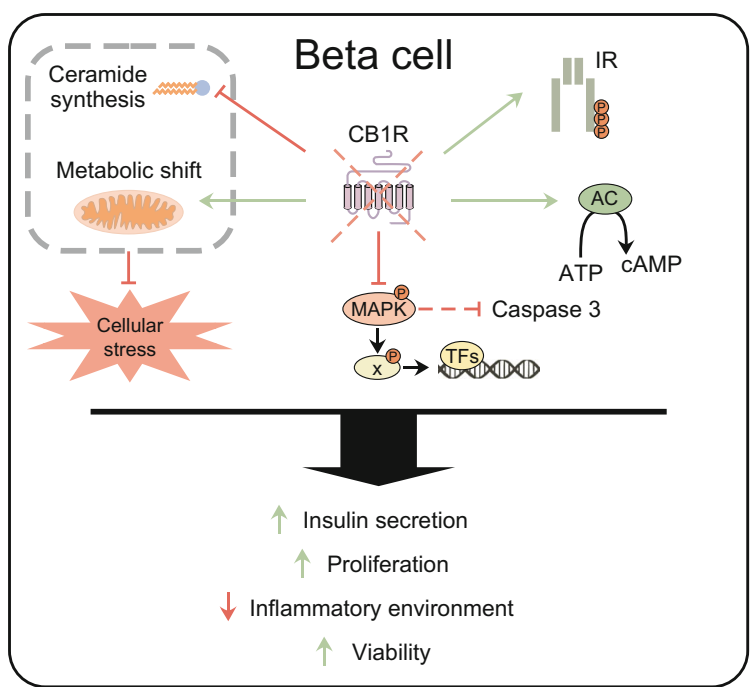

Fig. 8 Suggested mechanism of action of CB1R in pancreatic beta cells. Absence of CB1R, or its pharmacological blockade, increases IR sensitivity and $\mathrm{AC}$ activity. Ablation of CB1R also blocks ceramide synthesis and induces a metabolic shift towards reduced mitochondrial respiration, reducing cellular oxidative stress. In addition, ablation of CB1R lowers MAPK activation by phosphorylation and therefore its downstream signalling $(\mathrm{X})$, leading to reduced activity of transcription factors (TFs) that regulate inflammatory cytokines and caspase 3 cleavage. Taken together, these changes lead to improved beta cell functional capacity, as demonstrated by increased insulin secretion, increased preservation of beta cell mass by inducing beta cell proliferation, and improved beta cell viability through a reduction in the inflammatory environment

cAMP, and activated by ROS and ceramides [22, 36]. The absence of CB1R facilitated increased cAMP levels and reduced ceramide production, key factors in reducing inflammation in $\beta$ $\mathrm{CB} 1 \mathrm{R}^{-/-}$mice. The expression of $C n r 2$ was also reduced in $\beta-$ $\mathrm{CB} 1 \mathrm{R}^{-/-}$islets, most likely due to reduced macrophage infiltration or numbers of resident islet macrophages, since macrophages have high expression levels of $\mathrm{Cnr} 2$. Moreover, chronic activation of CB1R and CB2R by synthetic agonists in human islets ex vivo did not affect beta cell viability, suggesting that crosstalk between the ECS of beta cells and immune cells is required for HFHS diet-induced immune cell infiltration in and around islets. It has been stated that production of ROS by mitochondria is obligatory for insulin secretion since it is a necessary by-product of ATP production [57]. However excess ROS production, when insulin secretion is under constant high demand such as with an HFHS diet, would eventually be detrimental to beta cells. Lack of CB1R induced a metabolic shift, with a reduction in mitochondrial glucose-stimulated oxygen consumption. ROS production and overall oxidative damage were lowered, aiding in preserving beta cell viability. We observed lower levels of TXNIP, a direct activator of NLRP3 and indicator of ROS damage [36-38], in the islets of HFHS- $\beta-\mathrm{CB}^{-/ \mathrm{R}^{--}}$compared with HFHS- $\beta-\mathrm{CB} 1 \mathrm{R}^{+/+}$mice.

In summary, CB1R exerts control over beta cell function, proliferation, viability and intracellular signalling (Fig. 8). We can now speculate why an autonomous ECS exists in beta cells. Many toxins that are no longer a threat to humans in the developed world because of vaccinations and antibiotics increase intra-beta cell cAMP, leading to possible death from hypoglycaemia because of hyperinsulinaemia. The presence of a robust intrinsic system, such as the ECS, to reduce intracellular cAMP and limit insulin secretion under duress probably provided a survival advantage. Simultaneously enhancing the ability of beta cells to attract immune cells to eliminate bacterial antigens, cell debris, islet amyloid polypeptide deposition, toxins and plasmids would also have been beneficial. We postulate that the ECS evolved in islets to serve a dual function: to diminish the effects of AC activators while increasing the ability of beta cells to protect themselves. Islets express all the machinery to synthesise ECs on demand $[4,5]$ and, similar to insulin, ECs (mainly 2arachidonoylglycerol) are secreted from the islets upon glucose stimulation [4]. Unfortunately our Westernised diets, high in fats and glucose, lead to a near-constant demand for insulin, increased synthesis of islet amyloid polypeptide and possibly increases in bacterial antigens from the gut, increased overall chemokine production, intra-islet inflammation, islet EC secretion, and over-activation of the islet ECS, eventually leading to beta cell dysfunction and hyperglycaemia. Pharmacological blockade of CB1R or hepatocyte CB1R nullification improves insulin action and reduces fat deposition in the liver $[12,19]$. Furthermore, CB1R inhibition in the periphery lowers insulin resistance $[12$, 19]. We now report that CB1R blockade improves beta cell function and protects against HFHS-induced islet inflammation, and may represent a therapeutic strategy in diabetes and impaired glucose tolerance. It has recently been reported that peripheral CB1R blockade in mice with impaired glucose tolerance improved glucose handling and resulted in several antiinflammatory and cytoprotective actions [58]. Nonetheless our study has the limitation that the rodent and human islet ECS are not identical, and further studies in humans are therefore needed. Previously [8], we found that human beta cells and hepatocytes, but not brain, predominantly express an isoform of CB1R, CB1b. Pharmacological blockade or morpholino oligos [59] to block CB1b mRNA transcription may lead to novel therapies for type 2 diabetes.

Acknowledgements MIP-Cre/ERT mice were kindly donated by L. Philipson (Department of Medicine, University of Chicago, Chicago, IL, USA). S961 was a donation from Novo Nordisk. JD-5037 was a donation from Jenrin Discovery (J. F. McElroy and R. Chorvat). The study sponsors were not involved in the design of the study, the collection, analysis or interpretation of data, writing the report, or the decision to submit for publication.

Data availability Microarray data have been deposited at GEO (GSE102027). The data generated during the current study are available from the corresponding author on reasonable request.

Funding This work was supported by the Intramural Research Programs of the National Institute on Aging in the National Institutes of Health. 
Duality of interest The authors declare that there is no duality of interest associated with this manuscript.

Contribution statement IGM conceptualised, designed and performed the majority of experiments, and analysed, interpreted and organised the data. JME conceptualised and designed the experiments, and interpreted the data. IGM and JME drafted the article. RAM performed and analysed immunohistochemistry staining. MED performed the islet perifusion. Q-RL, EL, YZ and KGB performed and analysed the microarray. SSC carried out immune cell isolation and profiling by flow cytometry. SG quantified ECs. All authors substantially contributed to acquisition, analysis and interpretation of data. All authors reviewed and approved the published version of the article. JME is the guarantor of this work and, as such, had full access to all the data in the study and takes responsibility for the integrity of the data and the accuracy of the data analysis.

Open Access This article is distributed under the terms of the Creative Commons Attribution 4.0 International License (http:// creativecommons.org/licenses/by/4.0/), which permits unrestricted use, distribution, and reproduction in any medium, provided you give appropriate credit to the original author(s) and the source, provide a link to the Creative Commons license, and indicate if changes were made.

\section{References}

1. Fu Z, Gilbert ER, Liu D (2012) Regulation of insulin synthesis and secretion and pancreatic beta-cell dysfunction in diabetes. Curr Diabetes Rev 9:25-53

2. Kim W, Egan JM (2008) The role of incretins in glucose homeostasis and diabetes treatment. Pharmacol Rev 60:470-512

3. Alberti KGMM, Juel Christensen N, Engkjær Christensen S et al (1973) Inhibition of insulin secretion by somatostatin. Lancet 302: 1299-1301

4. Kim W, Doyle ME, Liu Z et al (2011) Cannabinoids inhibit insulin receptor signaling in pancreatic $\beta$-cells. Diabetes 60:1198-1209

5. Bermúdez-Silva FJ, Suárez J, Baixeras E et al (2008) Presence of functional cannabinoid receptors in human endocrine pancreas. Diabetologia 51:476-487

6. Malenczyk K, Jazurek M, Keimpema E et al (2013) CB1 cannabinoid receptors couple to focal adhesion kinase to control insulin release. J Biol Chem 288:32685-32699

7. Bermúdez-Silva FJ, Suárez Pérez J, Nadal A et al (2009) The role of the pancreatic endocannabinoid system in glucose metabolism. Best Pract Res Clin Endocrinol Metab 23:87-102

8. González-Mariscal I, Krzysik-Walker SM, Doyle ME et al (2016) Human CB1 receptor isoforms, present in hepatocytes and $\beta$-cells, are involved in regulating metabolism. Sci Rep 6:33302

9. Engeli S (2008) Dysregulation of the endocannabinoid system in obesity. J Neuroendocrinol 20(Suppl 1):110-115

10. Maccarrone M, Bab I, Bíró Tet al (2015) Endocannabinoid signaling at the periphery: 50 years after THC. Trends Pharmacol Sci 36:277-296

11. O'Keefe L, Simcocks AC, Hryciw DH, Mathai ML, McAinch AJ (2014) The cannabinoid receptor 1 and its role in influencing peripheral metabolism. Diabetes Obes Metab 16:294-304

12. Cinar R, Godlewski G, Liu J et al (2014) Hepatic cannabinoid-1 receptors mediate diet-induced insulin resistance by increasing de novo synthesis of long-chain ceramides. Hepatology 59:143-153

13. Mackie K, Hille B (1992) Cannabinoids inhibit N-type calcium channels in neuroblastoma-glioma cells. Proc Natl Acad Sci U S A 89:3825-3829

14. Dalton G, Bass C, Van Horn C, Howlett A (2009) Signal transduction via cannabinoid receptors. CNS Neurol Disord - Drug Targets 8:422-431
15. Spivak CE, Kim W, Liu Q-R, Lupica CR, Doyle ME (2012) Blockade of $\beta$-cell $\mathrm{K}_{\mathrm{ATP}}$ channels by the endocannabinoid, 2arachidonoylglycerol. Biochem Biophys Res Commun 423:13-18

16. Bermudez-Silva FJ, Viveros MP, McPartland JM (2010) Rodriguez de Fonseca F. The endocannabinoid system, eating behavior and energy homeostasis: the end or a new beginning? Pharmacol Biochem Behav 95:375-382

17. Zimmer A, Zimmer AM, Hohmann AG, Herkenham M, Bonner TI (1999) Increased mortality, hypoactivity, and hypoalgesia in cannabinoid CB1 receptor knockout mice. Proc Natl Acad Sci 96:5780-5785

18. Jourdan T, Szanda G, Cinar R et al (2017) Developmental role of macrophage cannabinoid-1 receptor signaling in type 2 diabetes. Diabetes 66:994-1007

19. Tam J, Cinar R, Liu J et al (2012) Peripheral cannabinoid-1 receptor inverse agonism reduces obesity by reversing leptin resistance. Cell Metab 16:167-179

20. Kim W, Lao Q, Shin Y-K et al (2012) Cannabinoids induce pancreatic $\beta$-cell death by directly inhibiting insulin receptor activation. Sci Signal 5:ra23

21. Juan-Pico P, Fuentes E, Bermudez-Silva FJ et al (2006) Cannabinoid receptors regulate $\mathrm{Ca}^{2+}$ signals and insulin secretion in pancreatic $\beta$-cell. Cell Calcium 39:155-162

22. Jourdan T, Godlewski G, Cinar R et al (2013) Activation of the Nlrp3 inflammasome in infiltrating macrophages by endocannabinoids mediates beta cell loss in type 2 diabetes. Nat Med 19:1132-1140

23. Nakata M, Yada T (2008) Cannabinoids inhibit insulin secretion and cytosolic $\mathrm{Ca}^{2+}$ oscillation in islet $\beta$-cells via CB1 receptors. Regul Pept 145:49-53

24. González-Mariscal I, Krzysik-Walker SM, Kim W, Rouse M, Egan JM (2016) Blockade of cannabinoid 1 receptor improves GLP-1R mediated insulin secretion in mice. Mol Cell Endocrinol 423:1-10

25. Chen H, Martin B, Cai H et al (2013) Pancreas++: automated quantification of pancreatic islet cells in microscopy images. Front Physiol 3:482

26. Cheadle C, Vawter MP, Freed WJ, Becker KG (2003) Analysis of microarray data using $\mathrm{Z}$ score transformation. J Mol Diagnostics 5: 73-81

27. Stewart AF, Hussain MA, García-Ocaña A et al (2015) Human $\beta$ cell proliferation and intracellular signaling: part 3. Diabetes 64: 1872-1885

28. Yi P, Park J-S, Melton DA (2013) Betatrophin: a hormone that controls pancreatic $\beta$ cell proliferation. Cell 153:747-758

29. Graham LB (1924) Animal calorimetry: twenty-fourth paper. Analysis of the oxidation of mixtures of carbohydrate and fat. J Biol Chem 59:41-44

30. Shimomura I, Matsuda M, Hammer RE, Bashmakov Y, Brown MS, Goldstein JL (2000) Decreased IRS-2 and increased SREBP-1c lead to mixed insulin resistance and sensitivity in livers of lipodystrophic and $o b / o b$ mice. Mol Cell 6:77-86

31. Pertwee RG (2005) Inverse agonism and neutral antagonism at cannabinoid CB1 receptors. Life Sci 76:1307-1324

32. Ma L, Jia J, Niu W et al (2015) Mitochondrial CB1 receptor is involved in ACEA-induced protective effects on neurons and mitochondrial functions. Sci Rep 5:12440

33. Mendizabal-Zubiaga J, Melser S, Bénard G et al (2016) Cannabinoid CB1 receptors are localized in striated muscle mitochondria and regulate mitochondrial respiration. Front Physiol 7: 476

34. Keane K, Newsholme P (2014) Metabolic regulation of insulin secretion. In: Litwack J (ed) Vitamins \& Hormones. Elsevier, Amsterdam, pp 1-33

35. López-Lluch G, Navas P (2016) Calorie restriction as an intervention in ageing. J Physiol 594:2043-2060

36. Vandanmagsar B, Youm Y-H, Ravussin A et al (2011) The NLRP3 inflammasome instigates obesity-induced inflammation and insulin resistance. Nat Med 17:179-188 
37. Maedler K, Sergeev P, Ris F et al (2002) Glucose-induced $\beta$ cell production of IL-1 $\beta$ contributes to glucotoxicity in human pancreatic islets. J Clin Invest 110:851-860

38. Zhou R, Tardivel A, Thorens B, Choi I, Tschopp J (2010) Thioredoxin-interacting protein links oxidative stress to inflammasome activation. Nat Immunol 11:136-140

39. Kelleher ZT, Sha Y, Foster MW, Foster WM, Forrester MT, Marshall HE (2014) Thioredoxin-mediated denitrosylation regulates cytokine-induced nuclear factor $\mathrm{\kappa B}(\mathrm{NF}-\mathrm{\kappa B})$ activation. $\mathrm{J}$ Biol Chem 289:3066-3072

40. Westwell-Roper C, Nackiewicz D, Dan M, Ehses JA (2014) Tolllike receptors and NLRP3 as central regulators of pancreatic islet inflammation in type 2 diabetes. Immunol Cell Biol 92:314-323

41. Sakurai H, Suzuki S, Kawasaki N et al (2003) Tumor necrosis factor- $\alpha$-induced IKK phosphorylation of NF-kB p65 on serine 536 is mediated through the TRAF2, TRAF5, and TAK1 signaling pathway. J Biol Chem 278:36916-36923

42. Cheon H, Cho JM, Kim S et al (2010) Role of JNK activation in pancreatic $\beta$-cell death by streptozotocin. Mol Cell Endocrinol 321: $131-137$

43. Fonseca SG, Gromada J, Urano F (2011) Endoplasmic reticulum stress and pancreatic $\beta$-cell death. Trends Endocrinol Metab 22: 266-274

44. Vetere A, Choudhary A, Burns SM, Wagner BK (2014) Targeting the pancreatic $\beta$-cell to treat diabetes. Nat Rev Drug Discov 13: 278-289

45. Li L, El-Kholy W, Rhodes CJ, Brubaker PL (2005) Glucagon-like peptide-1 protects beta cells from cytokine-induced apoptosis and necrosis: role of protein kinase B. Diabetologia 48:1339-1349

46. Malenczyk K, Keimpema E, Piscitelli F et al (2015) Fetal endocannabinoids orchestrate the organization of pancreatic islet microarchitecture. Proc Natl Acad Sci U S A 112:E6185-E6194

47. Romero-Zerbo SY, Rafacho A, Díaz-Arteaga A et al (2011) A role for the putative cannabinoid receptor GPR55 in the islets of Langerhans. J Endocrinol 211:177-185

48. Marban SL, Deloia JA, Gearhart JD (1989) Hyperinsulinemia in transgenic mice carrying multiple copies of the human insulin gene. Dev Genet 10:356-364
49. Yang X, Mei S, Gu H et al (2014) Exposure to excess insulin (glargine) induces type 2 diabetes mellitus in mice fed on a chow diet. J Endocrinol 221:469-480

50. Shimomura K, Tusa M, Iberl M et al (2013) A mouse model of human hyperinsulinism produced by the E1506K mutation in the sulphonylurea receptor SUR1. Diabetes 62:3797-3806

51. Ravinet Trillou C, Delgorge C, Menet C, Arnone M, Soubrié P (2004) CB1 cannabinoid receptor knockout in mice leads to leanness, resistance to diet-induced obesity and enhanced leptin sensitivity. Int J Obes Relat Metab Disord 28:640-648

52. Nogueiras R, Diaz-Arteaga A, Lockie SH et al (2009) The endocannabinoid system: role in glucose and energy metabolism. Pharmacol Res 60:93-98

53. Cettour-Rose P, Samec S, Russell AP et al (2005) Redistribution of glucose from skeletal muscle to adipose tissue during catch-up fat: a link between catch-up growth and later metabolic syndrome. Diabetes 54:751-756

54. Ueno M, Carvalheira JBC, Tambascia RC et al (2005) Regulation of insulin signalling by hyperinsulinaemia: role of IRS- $1 / 2$ serine phosphorylation and the mTOR/p70 S6K pathway. Diabetologia 48:506-518

55. Hebert-Chatelain E, Desprez T, Serrat R et al (2016) A cannabinoid link between mitochondria and memory. Nature 539:555-559

56. Valvona CJ, Fillmore HL, Nunn PB, Pilkington GJ (2016) The regulation and function of lactate dehydrogenase $\mathrm{A}$ : therapeutic potential in brain tumor. Brain Pathol 26:3-17

57. Leloup C, Tourrel-Cuzin C, Magnan C et al (2009) Mitochondrial reactive oxygen species are obligatory signals for glucose-induced insulin secretion. Diabetes 58:673-681

58. Romero-Zerbo SY, Ruz-Maldonado I, Espinosa-Jiménez V et al (2017) The cannabinoid ligand LH-21 reduces anxiety and improves glucose handling in diet-induced obese pre-diabetic mice. Sci Rep 7:3946

59. Echigoya Y, Nakamura A, Nagata T et al (2017) Effects of systemic multiexon skipping with peptide-conjugated morpholinos in the heart of a dog model of Duchenne muscular dystrophy. Proc Natl Acad Sci U S A 114:4213-4218 